\title{
Effect of Annealing Temperature and Atmosphere to Surface Solid Phase Reaction of Sapphire Substrates and Spin-Coated Copper Nitrate Gel Films
}

\author{
Takashi Ehara \\ Faculty of Human Studies, Ishinomaki Senshu University, Ishinomaki, Japan \\ Email: ehara@isenshu-u.ac.jp
}

How to cite this paper: Ehara, T. (2018) Effect of Annealing Temperature and Atmosphere to Surface Solid Phase Reaction of Sapphire Substrates and Spin-Coated Copper Nitrate Gel Films. Journal of Materials Science and Chemical Engineering, 6, 1-10.

https://doi.org/10.4236/msce.2018.65001

Received: April 11, 2018

Accepted: May 22, 2018

Published: May 25, 2018

Copyright $\odot 2018$ by author and Scientific Research Publishing Inc. This work is licensed under the Creative Commons Attribution International License (CC BY 4.0).

http://creativecommons.org/licenses/by/4.0/

\begin{abstract}
The solid-phase reaction of sapphire $\left(\mathrm{Al}_{2} \mathrm{O}_{3}\right)$ substrates and spin-coated copper nitrate films was studied. X-ray diffraction analysis revealed that a $\mathrm{CuO}$ fraction was observed by annealing at temperatures higher than $800^{\circ} \mathrm{C}$. In addition, crystalline $\mathrm{CuAlO}_{2}$ was formed at annealing temperatures in the range of $900^{\circ} \mathrm{C}-1000^{\circ} \mathrm{C}$ by solid-phase reaction of the spin-coated films and sapphire substrate. Crystalline $\mathrm{CuAlO}_{2}$ was formed by annealing at $1000^{\circ} \mathrm{C}$ for 5 $10 \mathrm{~h}$, and $\mathrm{CuAl}_{2} \mathrm{O}_{4}$ was formed by annealing at $1000^{\circ} \mathrm{C}$ for $15 \mathrm{~h}$. When annealing under $\mathrm{N}_{2}$ flow, $\mathrm{Cu}_{2} \mathrm{O}$ was observed rather than $\mathrm{CuAlO}_{2}$. For a sample annealed in air at $1000^{\circ} \mathrm{C}$ for $5 \mathrm{~h}, \mathrm{X}$-ray photoelectron spectroscopy measurements at various depths from surface revealed that $\mathrm{Cu}^{2+}$ ions are located around the surface, which suggests that the $\mathrm{CuO}$ fraction is present near the surface while the $\mathrm{CuAlO}_{2}$ fraction is located at greater depths from the surface of the samples. The depth profile of the sample suggests that there is no pure $\mathrm{CuAlO}_{2}$ layer in the sample, but that crystalline $\mathrm{CuAlO}_{2}$ is present in the sample as a mixture with $\mathrm{CuO}$ and $\mathrm{Al}_{2} \mathrm{O}_{3}$.
\end{abstract}

\section{Keywords}

Solid-Phase Reaction, Sapphire Substrate, $\mathrm{CuAlO}_{2}, \mathrm{CuO}, \mathrm{X}$-Ray Diffraction, X-Ray Photoelectron Spectroscopy

\section{Introduction}

$\mathrm{Cu}$-delafossite, which comprises ternary metal oxide materials with a structure of $\mathrm{CuMO}_{2}(\mathrm{M}=\mathrm{Al}, \mathrm{Ga}$, In, Sc, $\mathrm{Y}, \mathrm{La}, \mathrm{Cr}, \mathrm{Fe}$, etc. $)$ has gathered much interest due 
to their potential in various applications, such as wide gap semiconductors [1] [2] [3], catalysts [4] [5] or sensors [6]. Among the Cu-delafossite materials, $\mathrm{Cu}$ $\mathrm{AlO}_{2}$ is considered a promising candidate as a p-type transparent conductive oxide (TCO) [1]. Some TCO materials, such as indium tin oxide [7] or aluminum-doped zinc oxide [8], have already been studied and applied in optoelectronic devices. However, most TCOs have n-type conductivity, so that TCO materials with p-type conductivity have been in demand to prepare transparent pn junctions. The properties of $\mathrm{CuAlO}_{2}$ as a p-type TCO have been reported, such as an optical bandgap of $3.5 \mathrm{eV}$ and conductivity of $1 \Omega \mathrm{cm}$ [1]. $\mathrm{CuAlO}_{2}$ thin films have been prepared by various methods, including pulsed laser deposition [1] [9] [10], sputtering [11] [12] [13] [14], chemical vapor deposition [15] [16], solid-phase reaction of $\mathrm{Al}_{2} \mathrm{O}_{3}$, sapphire substrate, and $\mathrm{Cu}_{2} \mathrm{O}$ thin layers [17] [18], chemical spray pyrolysis [19], and the sol-gel method [20] [21] [22] [24]. Among these preparation methods, the solid-phase reaction of sapphire substrate and $\mathrm{Cu}_{2} \mathrm{O}$ is interesting because the $\mathrm{CuAlO}_{2}$ layer formed on the surface of the sapphire substrate can act as a transparent electrode with strong adhesion to the sapphire substrate. On the other hand, the sol-gel method has been studied extensively as a method for the preparation of $\mathrm{CuAlO}_{2}$ thin films. In the studies of sol-gel preparation, various aluminum source materials have been used, such as aluminum acetate [20], aluminum ethoxide [21], aluminum nitrate [22] [23], or alumatrane [24]. In addition, some of those aluminum sources do not have an exact molecular weight due to hydration water. On the other hand, the preparation of copper oxide by sol-gel method has been well established. $\mathrm{CuO}$ or $\mathrm{Cu}_{2} \mathrm{O}$ thin films have been successfully prepared using the sol-gel method [25] [26]. The sol-gel films become $\mathrm{CuO}$ or $\mathrm{Cu}_{2} \mathrm{O}$ thin films depending on the annealing temperature or annealing atmosphere. Films annealed under nitrogen flow at temperatures higher than $900^{\circ} \mathrm{C}$ generally become $\mathrm{Cu}_{2} \mathrm{O}$ thin films, whereas $\mathrm{CuO}$ films are formed by annealing in air at lower temperatures [25].

In the present work, $\mathrm{CuAlO}_{2}$ layers were prepared on the surface of sapphire substrates by solid-phase reaction of the sapphire substrate with spin-coated copper nitrate thin films. This method makes it possible to form a $\mathrm{CuAlO}_{2}$ layer on the surface of sapphire substrate without the need for complicated vacuum equipment.

\section{Experimental}

A copper source solution was prepared by dissolving $2.42 \mathrm{~g}$ of copper(II) nitrate trihydrate in $25 \mathrm{~mL}$ of 2-methoxyethanol. The solution was stirred for $24 \mathrm{~h}$ to produce a light blue and homogenous solution. The solution was spin-coated onto a $c$-oriented single-side-polished sapphire substrate with a thickness of 0.5 $\mathrm{mm}$. Before spin-coating of the copper source solution, the sapphire substrates were degreased by ultrasonication in EtOH. Spin-coating was performed at 3000 $\mathrm{rpm}$ for $10 \mathrm{~s}$. The coated films were first heated at $200^{\circ} \mathrm{C}$ for $10 \mathrm{~min}$ in air, and then again at a higher temperature of $500^{\circ} \mathrm{C}$ for 20 min using a hot-plate as the 
heating device. Spin-coating and subsequent heat treatment procedures were repeated 6 times to obtain a gel film with a thickness of $0.2 \mu \mathrm{m}$. The prepared samples were annealed at temperatures in the range of $800^{\circ} \mathrm{C}-1100^{\circ} \mathrm{C}$ for $10 \mathrm{~h}$ in air or under nitrogen flow. In another experiment, the samples were annealed at $1000^{\circ} \mathrm{C}$ for $2,5,10$ and $15 \mathrm{~h}$ in air. The temperature was increased from room temperature to the specific temperature over a period of $3 \mathrm{~h}$, held at the specific temperature for $10 \mathrm{~h}$, and then cooled to room temperature over a period of more than $3 \mathrm{~h}$.

The structural properties of the films were analyzed using X-ray diffraction (XRD; D8 Discover, Bruker) in $\theta-2 \theta$ mode with $\mathrm{Cu} \mathrm{K} \alpha$ radiation. A Ni filter with a thickness of $0.12 \mathrm{~mm}$ was used to avoid observation of the signal due to $\mathrm{CuK} \beta$ radiation. The atomic compositions of the samples, including depth profiles, were measured using X-ray photoelectron spectroscopy (XPS; JPS-9010MC, JEOL) with $\mathrm{Mg} \mathrm{K} \alpha$ radiation. Depth profiles of the samples were measured by etching with Ar sputtering. The etch rate of the sapphire substrate with Ar sputtering was determined to be $10 \mathrm{~nm} / \mathrm{min}$. The atomic compositions were determined using a sapphire substrate as a standard sample for the Al/O ratio. The $\mathrm{Cu} / \mathrm{Al}$ ratios were determined using $\mathrm{CuAlO}_{2}$ films prepared by the sol-gel method as a standard sample using $\mathrm{Cu}$ and $\mathrm{Al}$ nitrates as metal sources.

\section{Results and Discussion}

Figure 1 shows XRD patterns of the sapphire substrate with spin-coated copper nitrate films annealed at various temperatures (a) in air and (b) under nitrogen flow. For annealing in air at $800^{\circ} \mathrm{C}$ or $900^{\circ} \mathrm{C}$, only peaks of $\mathrm{CuO}$ are observed. The CuO (110), (002)(-111) and (111) peaks are observed at $32.5^{\circ}, 35.5^{\circ}$, and $38.7^{\circ}$, respectively (PDF 00-045-0937). However, the samples annealed at $1000^{\circ} \mathrm{C}$ showed the (006) peak of $\mathrm{CuAlO}_{2}$ at $31.6^{\circ}$ (PDF 00-035-1401) in addition to the peaks of $\mathrm{CuO}$. At an annealing temperature of $1100^{\circ} \mathrm{C}$, all the $\mathrm{CuAlO}_{2}$ and $\mathrm{CuO}$ peaks disappeared, which is considered to be due to evaporation of the spin-coated copper nitrate film at high temperature before oxidation or reaction with the sapphire substrate could occur. The samples annealed under nitrogen flow showed different results. As shown in Figure 1(b), a peak of $\mathrm{Cu}_{2} \mathrm{O}$ was observed at $36.3^{\circ}$ (PDF 00-005-0667) in addition to the peaks of $\mathrm{CuO}$ at annealing temperatures higher than $900^{\circ} \mathrm{C}$. The intensity of the $\mathrm{Cu}_{2} \mathrm{O}$ peak increased with the annealing temperature up to $1000^{\circ} \mathrm{C}$, which is consistent with a previous study on films of $\mathrm{CuO}$ and $\mathrm{Cu}_{2} \mathrm{O}$ prepared by the sol-gel route on $\mathrm{SiO}_{2}$ substrates [25]. At an annealing temperature of $1000^{\circ} \mathrm{C}$, a $\mathrm{CuAlO}_{2}$ peak was observed at $31.7^{\circ}$, as was the case for the samples annealed in air; however, the intensity was very weak and the peak width was broadened.

The results indicate that the crystalline $\mathrm{CuAlO}_{2}$ in the sample has a small volume ratio and small crystallite size. At an annealing temperature of $1100^{\circ} \mathrm{C}$, no peaks were observed, similar to the samples annealed in air. Figure 2 shows wide angle range $\mathrm{XRD}$ patterns of the samples annealed in air or under nitrogen flow 

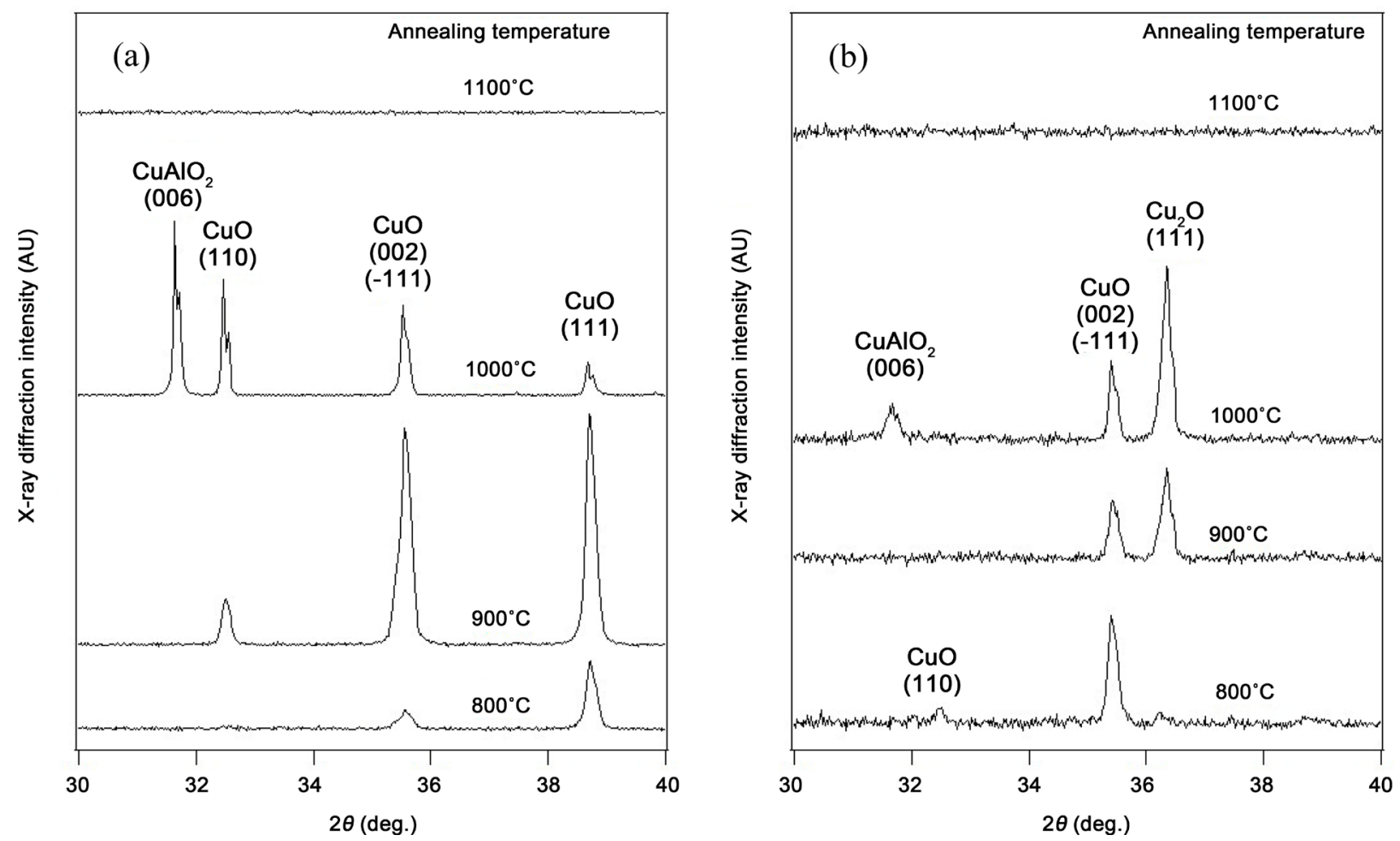

Figure 1. XRD patterns of sapphire substrates with spin-coated $\mathrm{Cu}\left(\mathrm{NO}_{3}\right)_{2}$ thin films annealed at various temperature for $10 \mathrm{~h}$ (a) in air, or (b) under nitrogen flow.

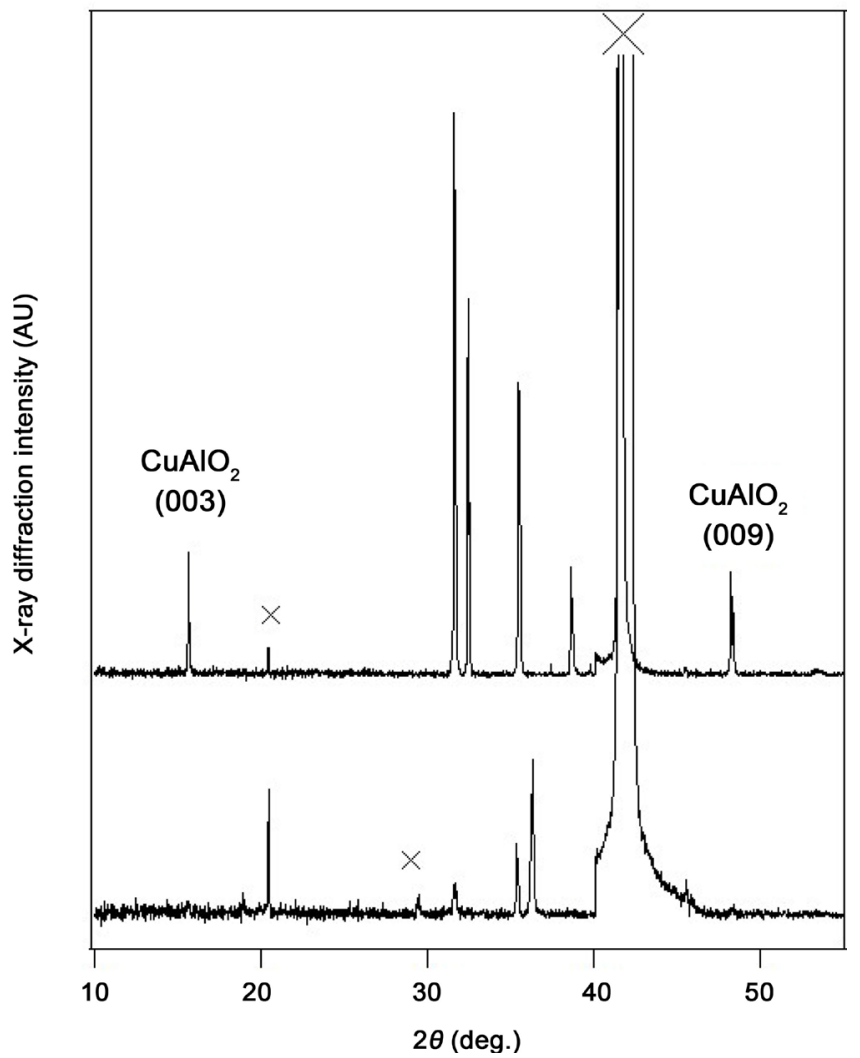

Figure 2. Wide angle range XRD patterns of samples annealed at $1000^{\circ} \mathrm{C}$ in air and under nitrogen flow. The peaks with cross mark are due to substrate. 
at $1000^{\circ} \mathrm{C}$ to compare the effect of the annealing atmosphere. For the sample annealed in air, peaks of $\mathrm{CuAlO}_{2}$ were observed at $15.6^{\circ}(003), 31.6^{\circ}(006)$, and $48.3^{\circ}$ (009). However, no peaks beside the $c$-axis oriented $\mathrm{CuAlO}_{2}$ peaks were observed, which indicates that the $\mathrm{CuAlO}_{2}$ in the samples is highly $c$-axis oriented. In contrast, the sample annealed under nitrogen flow shows only one (006) peak for $\mathrm{CuAlO}_{2}$ at $31.6^{\circ}$. These results indicate that annealing in air is more preferable than annealing under $\mathrm{N}_{2}$ flow to form $\mathrm{CuAlO}_{2}$ by solid-phase reaction between a spin-coated copper nitrate film and sapphire substrate. In the case of solid phase reaction of powders, the $\mathrm{CuAlO}_{2}$ formation reaction under nitrogen flow is preferable than in the air.

At the temperature of $1000^{\circ} \mathrm{C}$, copper oxide takes form of $\mathrm{Cu}_{2} \mathrm{O}$, even if the atmosphere includes oxygen gas. Thus, $\mathrm{CuAlO}_{2}$ is formed by the solid-phase reaction shown in (1) as well as in the case of solid phase reaction of powders [14].

$$
\mathrm{Cu}_{2} \mathrm{O}+\mathrm{Al}_{2} \mathrm{O}_{3} \rightarrow 2 \mathrm{CuAlO}_{2}
$$

However, the solid phase reaction in the present work is accompanied by diffusion of oxygen and copper into sapphire substrate. In the annealing under nitrogen flow, it is considered that the supply of oxygen to the reaction interface is not sufficient and the formation of $\mathrm{CuAlO}_{2}$ stops at a specific depth. As a result, the formation reaction of $\mathrm{CuAlO}_{2}$ by the annealing in air becomes rather preferable than that under nitrogen flow.

In the XRD patterns of the samples annealed in air, no peaks of $\mathrm{Cu}_{2} \mathrm{O}$ are observed, although $\mathrm{Cu}_{2} \mathrm{O}$ is required to the solid phase reaction to form $\mathrm{CuAlO}_{2}$. It is because the $\mathrm{Cu}_{2} \mathrm{O}$ which exist at the temperature of $1000^{\circ} \mathrm{C}$ is oxidized to $\mathrm{CuO}$ by air at lower temperature during the temperature decreasing process in the annealing.

$$
\mathrm{Cu}_{2} \mathrm{O}+1 / 2 \mathrm{O}_{2} \rightarrow \mathrm{CuO}
$$

As a result, XRD patterns show peaks of only $\mathrm{CuAlO}_{2}$ and $\mathrm{CuO}$.

Figure 3 shows XRD patterns of samples annealed at $1000^{\circ} \mathrm{C}$ in air for various times. The sample annealed for $2 \mathrm{~h}$ showed only peaks due to $\mathrm{CuO}$. In contrast, after annealing the sample for $5 \mathrm{~h}$, XRD peaks of $\mathrm{CuAlO}_{2}$ were observed with peaks of $\mathrm{CuO}$. After annealing of $10 \mathrm{~h}$, both $\mathrm{CuAlO}_{2}$ and $\mathrm{CuO}$ peaks were observed, as with the sample annealed for $5 \mathrm{~h}$. The intensity of both the $\mathrm{CuAlO}_{2}$ peaks increased with annealing time from $5 \mathrm{~h}$ to $10 \mathrm{~h}$. In the sample annealed at $1000^{\circ} \mathrm{C}$ for $15 \mathrm{~h}$, a different XRD pattern from the sample annealed for $10 \mathrm{~h}$ was observed. The sample does not show either $\mathrm{CuO}$ or $\mathrm{CuAlO}_{2}$ peaks, but instead peaks of $\mathrm{CuAl}_{2} \mathrm{O}_{4}$ are observed at $31.3^{\circ}$ (220) and 36.9 (311) (PDF 00-033-0448). These results suggest that $\mathrm{CuAlO}_{2}$ reacts with the sapphire substrate:

$$
2 \mathrm{CuAlO}_{2}+\mathrm{Al}_{2} \mathrm{O}_{3}+\mathrm{O} \rightarrow 2 \mathrm{CuAl}_{2} \mathrm{O}_{4}
$$

No specific annealing time was determined when the sample produced only the $\mathrm{CuAlO}_{2}$ crystalline phase. The sample annealed for more than $20 \mathrm{~h}$ showed no copper related XRD peaks. This is considered to be due to the further diffusion 
of $\mathrm{Cu}$ atoms into the sapphire substrate. This suggests that the samples annealed for more than $20 \mathrm{~h}$ become copper-doped sapphire substrates, whereby only XRD peaks of crystalline $\mathrm{Al}_{2} \mathrm{O}_{3}$ are observed.

Figure 4 shows an XPS spectrum for the surface of the sample annealed at $1000^{\circ} \mathrm{C}$ for $5 \mathrm{~h}$. Peaks of $\mathrm{Cu} 2 \mathrm{p}, \mathrm{O} 1 \mathrm{~s}$, and $\mathrm{Al} 2 \mathrm{p}$ are observed at binding energies of and $930-955 \mathrm{eV}, 531.2 \mathrm{eV}$, and $74.4 \mathrm{eV}$, respectively. Peaks at binding energies of 745, 766, and $780 \mathrm{eV}$ are ascribed to Auger electrons (O KLL). $\mathrm{Cu} 2 \mathrm{p}$ has

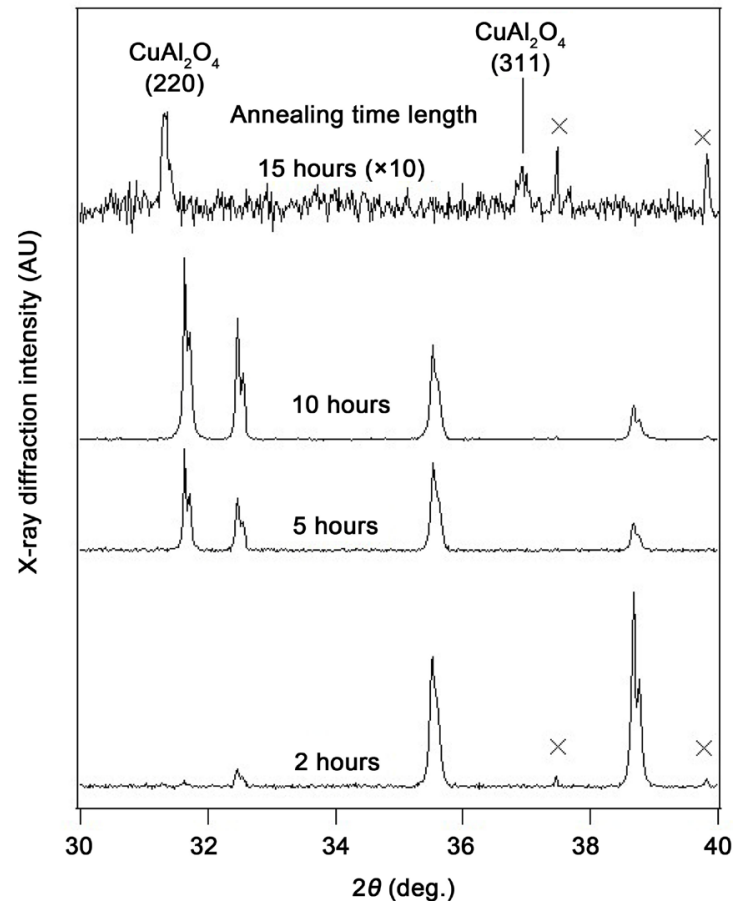

Figure 3. XRD patterns of sapphire substrates with spin-coated $\mathrm{Cu}\left(\mathrm{NO}_{3}\right)_{2}$ thin films heat treated for various times at $1000^{\circ} \mathrm{C}$ in air.

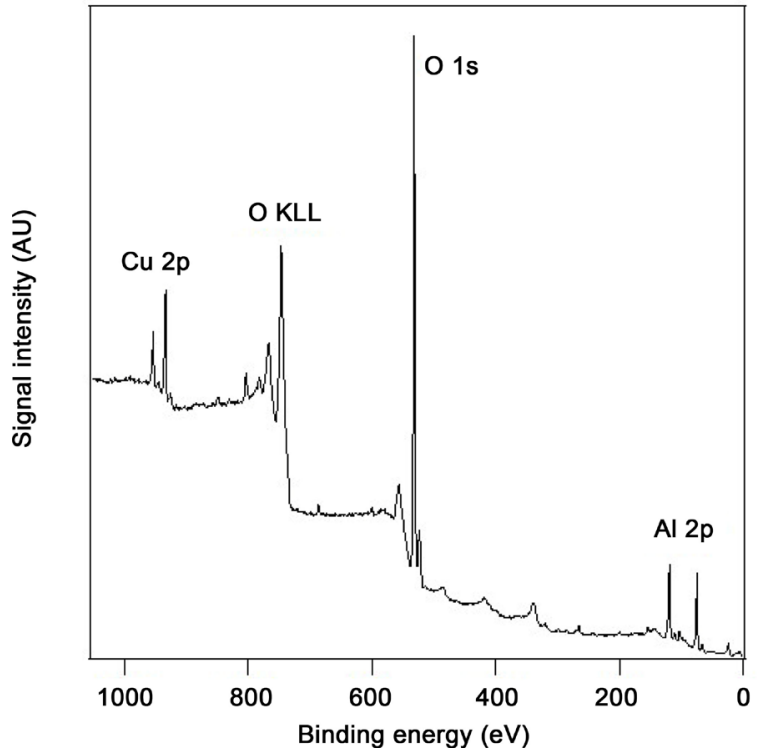

Figure 4. XPS spectrum for the surface of the sample annealed at $1000^{\circ} \mathrm{C}$ for $5 \mathrm{~h}$. 
two peaks at $933.4 \mathrm{eV}$ and $953.2 \mathrm{eV}$, which are assigned to $\mathrm{Cu} 2 \mathrm{p}_{3 / 2}$ and $\mathrm{Cu} 2 \mathrm{p}_{1 / 2}$, respectively. The peak positions observed in Figure 4 are shifted from those for $\mathrm{CuAlO}_{2}$ or $\mathrm{CuO}$ reported previously [27] [28] because the sample in the present work contains not only $\mathrm{CuAlO}_{2}$ and $\mathrm{CuO}$, but also $\mathrm{Cu}$-doped $\mathrm{Al}_{2} \mathrm{O}_{3}$.

Figure 5 shows depth profile of the atomic concentrations for the sample annealed at $1000^{\circ} \mathrm{C}$ for $5 \mathrm{~h}$. The atomic concentration of copper is $25 \%$ at the surface, which then decreases monotonically with increasing depth from the surface and becomes $0 \%$ at a depth of $450 \mathrm{~nm}$. XRD measurements showed the sample contains not only crystalline $\mathrm{CuAlO}_{2}$ but also crystalline $\mathrm{CuO}$; therefore, the sample is considered to consist of both of $\mathrm{CuAlO}_{2}$ and $\mathrm{CuO}$ fractions or layers embedded in the $\mathrm{Al}_{2} \mathrm{O}_{3}$ substrate. The XRD patterns of the sample measured after etching of the surface to $500 \mathrm{~nm}$ showed no copper related peaks.

Figure 6 shows XPS of $\mathrm{Cu} 2 \mathrm{p}, \mathrm{O} 1 \mathrm{~s}$, and $\mathrm{Al} 2 \mathrm{p}$ spectra at various depths from

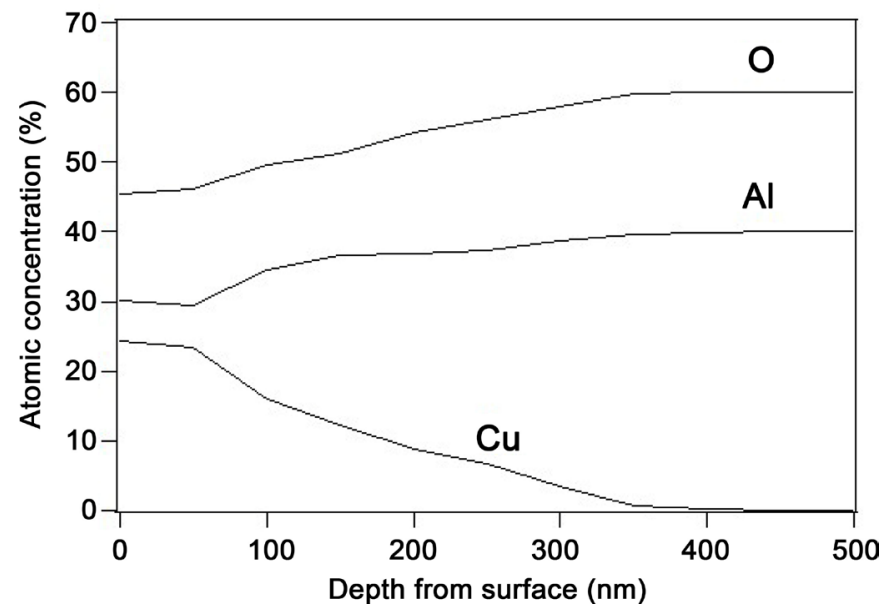

Figure 5. Depth profile of atomic concentration for the sample annealed at $1000^{\circ} \mathrm{C}$ for $5 \mathrm{~h}$.
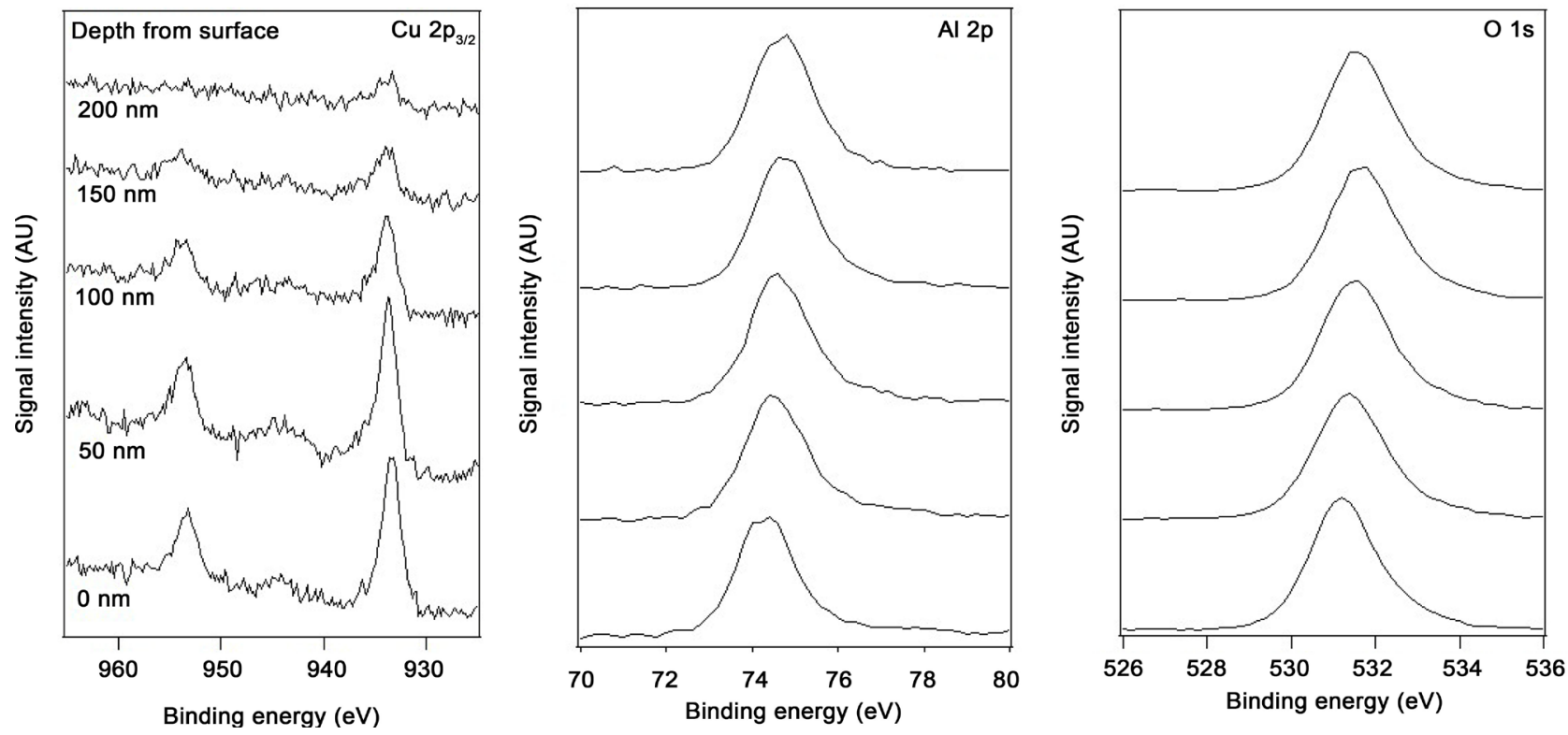

Figure 6. XPS of $\mathrm{Cu} 2 \mathrm{p}, \mathrm{Al} 2 \mathrm{p}$, and $\mathrm{O}$ 1s spectra measured at various depths from the surface. 
the surface. XPS peaks of $\mathrm{Cu} 2 \mathrm{p}$, i.e., $\mathrm{Cu} 2 \mathrm{p}_{3 / 2}$ at a binding energy of $933.5 \mathrm{eV}$ and $\mathrm{Cu} 2 \mathrm{p}_{1 / 2}$ peaks at $953.2 \mathrm{eV}$, are observed with a decrease in peak intensity with an increase in the depth from the surface. In addition, a weak and broad signal is also observed at a binding energy of $944 \mathrm{eV}$, which is assigned as a satellite peak that has been reported as a shake-up signal of $\mathrm{Cu}^{2+}$ [27]. It has been reported that the shake-up signal has not been observed in the case of $\mathrm{Cu}^{+}$, because of multiplet splitting of the signal [29]. The relative intensity of the signal at the surface is significantly weaker than that for pure $\mathrm{CuO}$ reported previously [30], which suggests that both $\mathrm{Cu}^{2+}$ and $\mathrm{Cu}^{+}$are present at the surface, so that both $\mathrm{CuO}$ and $\mathrm{CuAlO}_{2}$ are present at the surface. The relative intensity of the satellite peak to the peak at $933 \mathrm{eV}$ is dependent on the depth from the surface. The shake-up signal is clearly observed in the spectra measured at the surface and at a depth of $50 \mathrm{~nm}$. However, the satellite peak is not observed clearly at depths greater than $150 \mathrm{~nm}$, which indicates that $\mathrm{Cu}^{2+}$ is present mainly around the surface. Therefore, $\mathrm{CuO}$ is present at surface, while $\mathrm{CuAlO}_{2}$ is present at greater depths from the surface. In the case of the XPS $\mathrm{O} 1 \mathrm{~s}$ and $\mathrm{Al} 2 \mathrm{p}$ peaks shown in Figure 6, the dependence of the binding energy on the depth from surface was observed as a peak shift. At the surface, the $\mathrm{O} 1 \mathrm{~s}$ peak is observed at a binding energy of $531.2 \mathrm{eV}$, which is then is shifted to $531.5 \mathrm{eV}$ at a depth of $200 \mathrm{~nm}$ from the surface. The XPS Al $2 p$ peak at surface is observed at $74.4 \mathrm{eV}$, which is then shifted to $74.7 \mathrm{eV}$ at a depth of $200 \mathrm{~nm}$ from the surface. However, the peak shift is not significant, with the shift of binding energy at only $0.3 \mathrm{eV}$ for both the $\mathrm{O} 1 \mathrm{~s}$ and $\mathrm{Al} 2 \mathrm{p}$ peaks.

\section{Conclusion}

The solid-phase reaction of sapphire substrate and spin-coated copper nitrate thin films by thermal annealing was studied. XRD analysis revealed that both $\mathrm{CuO}$ and $\mathrm{CuAlO}_{2}$ fractions were formed at an annealing temperature of $1000^{\circ} \mathrm{C}$ for annealing times of $5 \mathrm{~h}$ or $10 \mathrm{~h}$. The formation of $\mathrm{CuO}$ is due to oxidation of the spin-coated copper nitrate gel film by the sol-gel route reaction. In contrast, the formation of $\mathrm{CuAlO}_{2}$ is evidence for the occurrence of a solid-phase reaction. XPS measurements revealed that $\mathrm{CuO}$ is present around the surface, while the $\mathrm{CuAlO}_{2}$ fraction is located at greater depths from the surface.

\section{Acknowledgements}

This work was financially supported by Ishinomaki Senshu University Kyoso Kenkyu Josei.

\section{References}

[1] Kawazoe, H., Yasukawa, M., Hyodo, H., Kurita, M., Yanagi, H. and Hosono, H. (1997) P-Type Electrical Conduction in Transparent Thin Films of $\mathrm{CuAlO}_{2}$. Nature (London), 389, 939-942. https://doi.org/10.1038/40087

[2] Ueda, K., Hase, T., Yanagi, H., Kawazoe, H., Hosono, H., Ohta, H., Orita, M. and Hirano, M. (2001) Epitaxial Growth of Transparent p-Type Conducting $\mathrm{CuGaO}_{2}$ 
Thin Films on Sapphire (001) Substrates by Pulsed Laser Deposition. Journal of Applied Physics, 89, 1790-1793. https://doi.org/10.1063/1.1337587

[3] Singh, M., Mehta, B.R., Varandari, D. and Singh, V.N. (2009) Electrical and Optical Properties of $\mathrm{Sn}$ Doped $\mathrm{CuInO}_{2}$ Thin Films: Conducting Atomic Force Microscopy and Spectroscopic Ellipsometry Studies. Journal of Applied Physics, 106, 053709. https://doi.org/10.1063/1.3211941

[4] Toyoda, K., Hinogami, R., Miyata, N. and Aizawa, M. (2015) Calculated Descriptors of Catalytic Activity for Water Electrolysis Anode: Application to Delafossite Oxides. The Journal of Physical Chemistry C, 119, 6495-6501.

https://doi.org/10.1021/jp5092398

[5] Amrute, A.P., Larrazábal, G.O., Mondelli, and C., Pérez-Ramírez, J. (2013) $\mathrm{CuCrO}_{2}$ Delafossite: A Stable Copper Catalyst for Chlorine Production. Angewandte Chemie International Edition, 52, 9772-9775. https://doi.org/10.1002/anie.201304254

[6] Thirumalairajan, S. and Mastelaro, V.R. (2016) A Novel Organic Pollutants Gas Sensing Material p-Type $\mathrm{CuAlO}_{2}$ Microsphere Constituted of Nanoparticles for Environmental Remediation. Sensors and Actuators B: Chemical, 223, 138-148. https://doi.org/10.1016/j.snb.2015.09.092

[7] Simashkevich, A., Serban, D., Bruc, L., Curmei, N., Hinrichs, V. and Rusu, M. (2016) Indium Tin Oxide Thin-Films Prepared by Vapor Phase Pyrolysis for Efficient Silicon Based Solar Cells. Thin Solid Films, 610, 35-41.

https://doi.org/10.1016/j.tsf.2016.04.047

[8] Kumar, B., Gong, H. and Akkipeddi, R. (2005) Aluminum-Doped Zinc Oxide Films as Transparent Conductive Electrode for Organic Lightemitting Devices. Journal of Applied Physics, 98, 073703. https://doi.org/10.1063/1.2060957

[9] Tonooka, K., Bando, H. and Aiura, Y. (2003) Photovoltaic Effect Observed in Transparent p-n Heterojunctions Based on Oxide Semiconductors. Thin Solid Films, 445, 327-331. https://doi.org/10.1016/S0040-6090(03)01177-5

[10] Neumann-Spallart, M., Pai, S.P. and Pinto, R. (2007) PLD Growth of $\mathrm{CuAlO}_{2}$. Thin Solid Films, 515, 8641-8644. https://doi.org/10.1016/j.tsf.2007.03.109

[11] Banerjee, A.N., Maity, R., Ghosh, P.K. and Chattopadhyay, K.K. (2005) Thermoelectric Properties and Electrical Characteristics of Sputterdeposited p-CuAlO 2 Thin Films. Thin Solid Films, 474, 261-266. https://doi.org/10.1016/j.tsf.2004.08.117

[12] Tsuboi, N., Moriya, T., Kobayashi, S., Shimizu, H., Kato, K. and Kaneko, F. (2008) Characterization of $\mathrm{CuAlO}_{2}$ Thin Films Prepared on Sapphire Substrates by Reactive Sputtering and Annealing. Japanese Journal of Applied Physics, 47, 592-595. https://doi.org/10.1143/JJAP.47.592

[13] Su, C.T., Lee, H.Y. Wu., B.K. and Chern, M.Y. (2011) Characterization of $\mathrm{CuAlO}_{2}$ Thin Films Prepared on Sapphire Substrates by Reactive Sputtering and Annealing. Journal of Crystal Growth, 328, 25-29. https://doi.org/10.1016/j.jcrysgro.2011.06.012

[14] Ehara, T., Iizaka, R., Abe, M., Abe, K. and Sato, T. (2017) Preparation of $\mathrm{CuAlO}_{2}$ Thin Films by Radio Frequency Magnetron Sputtering and the Effect of Sputtering on the Target Surface. Journal of Ceramic Science and Technology, 8, 7-12.

[15] Gong, H., Wang, Y. and Luo, Y. (2000) Nanocrystalline p-Type Transparent $\mathrm{Cu}-\mathrm{Al}-\mathrm{O}$ Semiconductor Prepared by Chemical-Vapor Deposition with $\mathrm{Cu}(\mathrm{acac})_{2}$ and $\mathrm{Al}(\mathrm{acac})_{3}$ Precursors. Applied Physics Letters, 76, 3959-3961. https://doi.org/10.1063/1.126834

[16] Cai, J. and Gong, H. (2005) The Influence of Cu/Al Ratio on Properties of Chemical-Vapor-Deposition Grown p-Type Cu-Al-O Transparent Semiconducting Films. 
Journal of Applied Physics, 98, Article ID: 033707. https://doi.org/10.1063/1.1997293

[17] Shy, J.H. and Tseng, B.H. (2005) Characterization of $\mathrm{CuAlO}_{2}$ Thin Film Prepared by Rapid Thermal Annealing of an $\mathrm{Al}_{2} \mathrm{O} 3 / \mathrm{Cu}_{2} \mathrm{O} /$ Sapphire Structure. Journal of Physics and Chemistry of Solids, 66, 2123-2126. https://doi.org/10.1016/j.jpcs.2005.09.062

[18] Shih, C.H. and Tseng, B.H. (2012) Formation Mechanism of $\mathrm{CuAlO}_{2}$ Prepared by Rapid Thermal Annealing of $\mathrm{Al}_{2} \mathrm{O}_{3} / \mathrm{Cu}_{2} \mathrm{O} /$ Sapphire Sandwich Structure. Physics Procedia, 32, 395-400. https://doi.org/10.1016/j.phpro.2012.03.574

[19] Kirupa, E.A., Raj, A.M.E. and Ravidhas, C. (2016) Influence of Substrate Temperature on Crystalline Copper Aluminium Oxide Thin Films Synthesized through Chemical Spray Pyrolysis (CSP) Technique. Journal of Materials Science: Materials in Electronics, 27, 8991-8995. https://doi.org/10.1007/s10854-016-4930-6

[20] Ehara, T., Abe, H., Iizaka, R., Abe, K. and Sato, T. (2017) Crystalline Orientation Control in Sol-Gel Preparation of $\mathrm{CuAlO}_{2}$ Thin Films. Journal of Sol-Gel Science and Technology, 82, 363-369. https://doi.org/10.1007/s10971-017-4306-2

[21] Ohashi, M., Iida, Y. and Morikawa, H. (2002) Preparation of $\mathrm{CuAlO}_{2}$ Films by Wet Chemical Synthesis. Journal of the American Ceramic Society, 85, 270-272. https://doi.org/10.1111/j.1151-2916.2002.tb00080.x

[22] Gosh, C.K., Popuri, S.R., Mahesh, T.U. and Chattopadhyay, K.K. (2009) Preparation of Nanocrystalline $\mathrm{CuAlO}_{2}$ through Sol-Gel Route. Journal of Sol-Gel Science and Technology, 52, 75-81. https://doi.org/10.1007/s10971-009-1999-x

[23] Liu, S.-J., Wang, H., Xu, J.-W., Ren, M.-F., Yang, L. and Ju, J.-H. (2011) Structure and Electrical Properties of $\mathrm{CuAlO}_{2}$ Thin Films Derived by Sol-Gel Processing. Journal of Materials Science: Materials in Electronics, 22, 666-671. https://doi.org/10.1007/s10854-010-0193-9

[24] Götzendörfer, S., Polenzky, C., Ulrich, S. and Löbmann, P. (2009) Preparation of $\mathrm{CuAlO}_{2}$ and $\mathrm{CuCrO}_{2}$ Thin Films by Sol-Gel Processing. Thin Solid Films, 518, 1153-1156. https://doi.org/10.1016/j.tsf.2009.02.153

[25] Aemelao, L., Barreca, D., Bertapelle, M., Bottaro, G., Sada, C. and Tondello, E. (2003) A Sol-Gel Approach to Nanophasic Copper Oxide Thin Films. Thin Solid Films, 442, 48-52. https://doi.org/10.1016/S0040-6090(03)00940-4

[26] Ray, S.C. (2001) Preparation of Copper Oxide Thin Film by the Sol-Gel Dip Technique and Study of Their Structural and Optical Properties. Solar Energy Materials and Solar Cells, 68, 307-312. https://doi.org/10.1016/S0927-0248(00)00364-0

[27] Liu, S., Wu, Z., Zhang, Y., Yao, Z., Fan, J., Zhang, Y., Zhang, P. and Shao, G. (2015) Strong Temperature-Dependent Crystallization, Phase Transition, Optical and Electrical Characteristics of $p$-Type $\mathrm{CuAlO}_{2}$ Thin Films. Physical Chemistry Chemical Physics, 17, 557-562. https://doi.org/10.1039/C4CP04009K

[28] Kim, D.-S. and Choi, S.-Y. (2005) Wet-Oxidation Effect on p-Type Transparent Conducting $\mathrm{CuAlO}_{2}$ Thin Film. Physica Status Solidi, 222, R167-R169.

[29] Ghijsen, J., Tjeng, L.H., Van Elp, J., Eskes, H., Westerink, J., Sawatzky, G.A. and Czyzyk, M.T. (1988) Electronic Structure of $\mathrm{Cu}_{2} \mathrm{O}$ and CuO. Physical Review B, Condensed Matter and Materials Physics, 38, 11322-11330. https://doi.org/10.1103/PhysRevB.38.11322

[30] Poulston, S., Parlett, P.M., Stone, P. and Bowker, M. (1996) Surface Oxidation and Reduction of $\mathrm{CuO}$ and $\mathrm{Cu}_{2} \mathrm{O}$ Studied Using XPS and XAES. Surface and Interface Analysis, 24, 811-820.

https://doi.org/10.1002/(SICI)1096-9918(199611)24:12<811::AID-SIA191>3.0.CO;2-Z 